\title{
Edukacyjne implikacje projektu dokumentacyjnego $i$ animacyjnego w środowisku lokalnym - między teorią a praktyką. „Historia Mówiona Miasta Lublina" Ośrodka Brama Grodzka - Teatr NN
}

\section{Historia mówiona w badaniach akademickich}

- perspektywy teoretyczno-metodologiczne

We współczesnej polskiej literaturze pojawia się coraz więcej publikacji odnoszących się do historii mówionej. Jest ona analizowana jako kierunek badań historycznych, nawiązujący do źródeł historiografii poprzez odwołanie się do indywidualnej pamięci ${ }^{1}$, a także jako odrębna metoda lub technika badawcza, wykorzystywana m.in. na gruncie historii czy socjologii, w ramach różnych orientacji teoretycznych i metodologicznych².

Zob. m.in.: M. Kurkowska-Budzan, Historia zwyktych ludzi. Wspótczesna angielska historiografia dziejów społecznych, Kraków 2003, s. 176.

2 Zob. m.in.: M. Halbwachs, Społeczne ramy pamięci, Warszawa 1969, s. 411; B. Szacka, O pamięci społecznej, „Znak” 1995, nr 480 (5), s. 68; P. Ricoeur, Pamięć - Zapomnienie - Historia, [w:] Tożsamość w czasach zmiany. Rozmowy w Castel Gandolfo, red. K. Michalski, Warszawa 1995, s. 27; K.L. Klein, O pojawieniu się pamięci w dyskursie historycznym, „Konteksty” 2003, nr 3-4, s. 42; F. Ankersmit, Postmodernistyczna "prywatyzacja” przeszłości, [w:] Frank Ankersmit. Narracja, reprezentacja, doświadczenie. Studia z teorii historiografii, red. E. Domańska, Kraków 2004, s. 376-378; E. Domańska, Wprowadzenie: Pamięć, etyka i historia, [w:] Pamięć, etyka i historia. 
Wzrost zainteresowania historią mówioną w różnego rodzaju projektach akademickich, wypływa - jak się wydaje - z jednej strony z rosnącego poczucia historyczności świata społecznego, z drugiej zaś - z rozwijania zainteresowań społeczną genezą zjawisk i procesów historycznych. Na poziomie ujęć teoretycznych, przejawem postępującego zbliżenia metodologicznego między społecznie i kulturowo zorientowaną historiografią a historycznie ukierunkowaną socjologią jest m.in. odchodzenie od ujęć modernistyczno-normatywnych, posługujących się empiryczno-ilościowym modelem pracy badawczej, w kierunku podejścia humanistycznego, akcentującego twórczy, aktywny udział człowieka w kształtowaniu rzeczywistości społecznej i historycznej³.

Badania odwołujące się do historii mówionej prowadzone są także na gruncie nauk pedagogicznych, w tym - w pedagogice społecznej. Dyscyplina ta, traktując wszelkie instytucje społeczne jako środowisko życia człowieka, dąży do intencjonalnego konstruowania i integrowania tego środowiska, tak aby stawało się ono środowiskiem wychowawczym zorientowanym na realizację takich wartości, jak: podmiotowość, partnerstwo, wolność, odpowiedzialność, tolerancja, solidarność, szacunek i empatia4. Tego rodzaju działania leżą - zdaniem pedagogów społecznych - u podstaw budowania społeczeństwa obywatelskiego, którego członko-

Anglo-amerykańska teoria historiografii lat dziewięćdziesiatych, red. Eadem, Poznań 2002; M. Kurkowska-Budzan, op. cit., s. 176; A. Nowak, Metoda biograficzna w badaniach pedagogicznych, [w:] Orientacje w metodologii badań pedagogicznych, red. S. Palka, Kraków 1998, s. 99; W. Theiss, Polsko-żydowska przeszłość: od historii do edukacji, „Wychowanie na co dzień” 20oo, nr 6, s. 15; Idem, Zniewolone dzieciństwo. Socjalizacja w skrajnych warunkach społeczno-politycznych, Warszawa 1996, s. 138; Idem, Badania biograficzne: przypadek dzieci syberyjskich, „Kwartalnik Pedagogiczny" 1988, nr 1, s. 133; K. Konecki, Studia z metodologii badań jakościowych. Teoria ugruntowana, Warszawa 2000, s. 180-183; P. Nora, Czas pamięci, „Res Publica Nowa" 2001, nr 7, s. 37.

3 P. Sztompka, Socjologiczna teoria podmiotowości, [w:] Podmiotowość, możliwość, rzeczywistość, konieczność, red. P. Buczkowski, R. Cichocki, Poznań 1988, s. 19.

4 W. Theiss, Edukacja środowiskowa - wprowadzenie, [w:] Edukacja i animacja spoteczna w środowisku lokalnym, red. W. Theiss, B. Skrzypczak, Warszawa 2006, s. 1318; zob. też: Pedagogika społeczna, kręgi poszukiwań, red. A. Przecławska, Warszawa 1997; Pedagogika społeczna, pytania o XXI wiek, red. A. Przecławska, W. Theiss, Warszawa 1999; S. Kawula, hasło: Pedagogika spoteczna, [w:] Encyklopedia pedagogiczna XXI wieku, t. IV, red. nauk. T. Pilch, Warszawa 2005, s. 264. 
wie posiadają kompetencje kulturowe i społeczne umożliwiające im pełną partycypację w życiu wspólnot lokalnych i narodowych ${ }^{5}$. W perspektywie praktyki pedagogicznej, kształtowanie postaw ukierunkowanych na realizację wymienionych wyżej wartości, wymaga m.in. odejścia od standaryzowanych form kształcenia na rzecz indywidualizacji procesu nauczania, rozwijania wyobraźni i krytycznego myślenia, kształcenia umiejętności porozumiewania się i działania w zespole, a także odwołania się w pracy dydaktycznej do szeroko rozumianego dziedzictwa społeczno-kulturowego środowiska lokalnego.

Nakreślone w ten sposób cele i zadania mogą być realizowane w ramach edukacji środowiskowej (zwanej też edukacją lokalną, community education, local education), rozumianej jako metoda organizowania społeczności lokalnej wokół określonych zadań społeczno-wychowawczych, a zarazem jako narzędzie zmiany społecznej ${ }^{6}$. Odwołanie się do historii mówionej na gruncie tego rodzaju edukacji służyć może nie tylko przekazywaniu wiedzy o środowisku i zacieśnianiu więzi międzypokoleniowych, ale też może wspierać działania na rzecz ochrony tożsamości historycznej i kulturowej, jak również - poprzez wzmacnianie procesów kształtowania poczucia podmiotowości jednostek i grup oraz aktywizowanie społeczności lokalnych - wspomagać rozwój demokracji i społeczeństwa obywatelskiego?.

Choć na gruncie literatury akademickiej pojawia się coraz więcej publikacji odnoszących się do zagadnień związanych z historią mówioną rozumianą jako element warsztatu badawczego, odrębna metoda badawcza,

5 Por. J. Delors, Edukacja - jest w niej ukryty skarb. Raport Międzynarodowej Komisji UNESCO do spraw Edukacji dla XXI wieku, Warszawa 1998, s. 47, 53, 55 i 92.

6 W. Theiss, Edukacja środowiskowa..., s. 12, 15, 18-23.

7 Przykładem działań odwołujących się do historii mówionej i mających charakter procesu szeroko rozumianej edukacji środowiskowej był realizowany w latach 1988-1991 przez grupę badaczy z Wydziału Pedagogicznego Uniwersytetu Warszawskiego projekt badawczo-edukacyjny „Pogwarki Węgrowskie”. Odczytywaniu obrazu miasta w perspektywie losów mieszkańców, towarzyszyły działania na rzecz zmiany kulturowo-edukacyjnych warunków środowiska lokalnego. Projekt ten miał w swych założeniach uczyć współdziałania i społecznej odwagi, kształtować postawy krytyczne; W. Theiss, „Pogwarki Wegrowskie”. Społeczna funkcja lokalnej historii, [w:] Węrów. Sity społeczne małego miasta, red. B. Smolińska-Theiss, Warszawa 1991, s. 91-121; zob. też: W. Theiss, Oral History in Poland (1996-1998), „Words and Silences. Bulletin of the International Oral History Association” 1998, nr 3, s. 38-40. 
czy specyficzne podejście teoretyczno-metodologiczne, rzadko podejmowane są pogłębione analizy dotyczące potencjału edukacyjnego, jaki niosą odnoszące się do historii mówionej społecznościowe projekty realizowane przez różnego rodzaju instytucje w całym kraju. W dostępnych publikacjach oraz na stronach internetowych znaleźć można informacje i materiały instruktażowe, mogące stanowić - dla zainteresowanych edukatorów i animatorów - punkt wyjścia do realizacji projektów dokumentacyjnych, tj. polegających na gromadzeniu wspomnień. Nadal stosunkowo mało jest jednak propozycji edukacyjnych (scenariuszy zajęć, dobrze opracowanych materiałów dla nauczycieli itp.) wykraczających w swej istocie poza nagrywanie, opracowywanie i archiwizowanie relacji, brakuje też badań naukowych ukierunkowanych na ewaluację rzeczywistego oddziaływania dydaktycznego tego typu projektów. Mimo iż dostrzegane są możliwości wykorzystania historii mówionej w szeroko rozumianej pracy edukacyjnej, niewielu badaczy podejmuje próbę osadzenia tej problematyki w szerszym kontekście współczesnych teorii pedagogicznych, koncepcji rozwijanych na gruncie animacji kultury, czy też rozważań dotyczących działań na rzecz upamiętniania przeszłości.

Punktem odniesienia do podejmowanych przez niektórych badaczy rozważań odnoszących się do edukacyjnego i wychowawczego potencjału historii mówionej jest najczęściej problematyka związana z odczytywaniem zasobów indywidualnej oraz zbiorowej pamięci. Przekonanie o edukacyjnych walorach historii mówionej wynika tu z przyjęcia założenia o istnieniu wzajemnych zależności między sposobem pamiętania i rozumienia przeszłości a myśleniem i postępowaniem w teraźniejszości. Wskazując na związki między wiedzą i świadomością historyczną a sferą wartości, przekonań, postaw oraz wynikających z nich działań podejmowanych przez jednostki i grupy, badacze podkreślają rolę historii mówionej w procesie rozwijania podmiotowości i historyczności indywidualnego życia, a także poczucia osadzenia w czasie i przestrzeni, będącego źródłem tożsamości, więzi z innymi członkami grupy oraz odpowiedzialności za jej losy ${ }^{8}$.

8 Zob. m.in.: J. Topolski, Świat bez historii, Warszawa 1976, s. 11; A. Szpociński, O historycznym $i$ socjologicznym rozumieniu kategorii "świadomość historyczna", [w:] Świadomość historyczna jako przedmiot badań historycznych, socjologicznych i historyczno-dydaktycznych, red. J. Taternicki, Warszawa 1985, s. 153. 
- odniesienia do teorii i praktyki

$\mathrm{Na}$ podstawie materiałów dostępnych na stronach internetowych można stwierdzić, iż w ciągu ostatnich 10 lat nastąpił w Polsce znaczny wzrost liczby projektów społecznościowych odwołujących się do historii mówionej, ukierunkowanych na budowanie przestrzeni obywatelskiej partycypacji, interakcji i społecznego dialogu, posiadających wyraźny wymiar szeroko rozumianej edukacji środowiskowej.

Obecnie w Polsce realizowanych jest kilkanaście większych projektów tego typu. Oprócz takich instytucji warszawskich, jak: Ośrodek KARTA i Dom Spotkań z Historią ${ }^{9}$, Muzeum Powstania Warszawskiego ${ }^{10}, \mathrm{Mu}$ zeum Warszawskiej Pragi ${ }^{11}$, Centrum Edukacji Obywatelskiej², projekty odwołujące się do historii mówionej realizują m.in.: wrocławski Ośrodek "Pamięć i Przyszłość”13, Ośrodek „Pogranicze Sztuk - Kultur - Narodów” w Sejnach ${ }^{14}$, Muzeum Warmii i Mazur w Olsztynie ${ }^{15}$, a także Ośrodek „Brama Grodzka - Teatr NN” w Lublinie ${ }^{16}$. Relacje mówione w formie audio i video nagrywane są także przez muzea - miejsca pamięci działające na terenie byłych niemieckich obozów koncentracyjnych i zagłady (m.in.: Państwowe Muzeum na Majdanku w Lublinie, Państwowe Muzeum Auschwitz-Birkenau w Oświęcimiu, Muzeum Gross-Rosen w Rogoźnicy) 17, a także przez wiele innych placówek różnego typu funkcjonujących na terenie całego kraju¹8. Część spośród wymienionych instytucji, poza

9 Zob.: http://www.karta.org.pl; http://www.dsh.waw.pl; http://audiohistoria.pl (dostęp: 21 VII 2012).

10 Zob.: http://www.1944.pl (dostęp: 21 VII 2012).

11 Zob.: http://www.muzeumpragi.pl/http://www.muzeumpragi.pl/index.php?m=23 (dostęp: 21 VII 2012).

12 Zob.: http://www.ceo.org.pl/portal/home (dostęp: 21 VII 2012).

13 Zob.: http://pamieciprzyszlosc.pl (dostęp: 21 VII 2012).

14 Zob.: http://pogranicze.sejny.pl/; http://pogranicze.sejny.pl/sejnenskie_karty_historyczne,1315.html (dostęp: 21 VII 2012).

15 Zob.: http://muzeum.olsztyn.pl/kresy; http://www.smok.hostil.pl (dostęp: 21 VII 2012).

16 Zob.: http://tnn.pl (dostęp: 21 VII 2012).

17 Zob.: http://www.majdanek.eu/; http://pl.auschwitz.org/m/; http://www.gross-rosen.eu/ (dostęp: 21 VII 2012).

18 Zob. m.in. M. Kubiszyn, Edukacja wielokulturowa w środowisku lokalnym. Studium teoretyczno-empiryczne na przykładzie Ośrodka „Brama Grodzka - Teatr NN” w Lublinie, Toruń 2007, s. 206-207. 
działaniami polegającymi na nagrywaniu, opracowywaniu, archiwizowaniu i udostępnianiu relacji (bezpośrednio oraz za pośrednictwem stron lub rozbudowanych portali internetowych), realizuje też różnego rodzaju projekty odnoszące się do historii mówionej i mające charakter edukacyjny, polegające m.in. na organizowaniu warsztatów i konkursów dla młodzieży ${ }^{19}$.

Odwołując się do literatury przedmiotu i do działań podejmowanych w praktyce, edukacyjne walory społecznościowych projektów odnoszących się do historii mówionej można analizować w co najmniej trzech nakładających się na siebie wymiarach. Pierwszy obejmuje zdobywanie wiedzy, rozwijanie umiejętności oraz kształtowanie kompetencji na poziomie indywidualnym przez uczestników projektów polegających na zbieraniu relacji; drugi - tworzenie - na poziomie instytucjonalnym i na podstawie zgromadzonych zasobów - oferty edukacyjnej skierowanej do społeczności lokalnej; trzeci - realizowanie przez osoby indywidualne oraz instytucje projektów artystycznych z wykorzystaniem relacji mówionych.

\subsection{Wiedza i kompetencje}

Wśród edukacyjnych wartości wynikających bezpośrednio z udziału w projektach polegających na zbieraniu historii mówionych, najczęściej przywoływane są (auto)dydaktyczne walory samego procesu nagrywania i opracowywania relacji, a także korzyści płynące z uczestnictwa w różnego rodzaju zespołowych formach aktywności, związanych z realizacją tego typu projektu. Poprzez nagrywanie wywiadów, w akcie bezpośredniej interakcji i komunikacji, u uczestników rozwijane mogą być takie, pożądane wychowawczo cechy, jak: empatia, cierpliwość, otwartość, sza-

19 Na przykład konkursy historyczne dla młodzieży „Historia Bliska”, organizowane od 1996 r. przez Ośrodek KARTA i Fundację Batorego, w ramach którego zebranych zostało ok. 7000 prac z całej Polski, czy projekt „Sprawiedliwy wśród narodów świata” i „Opowiem ci o wolnej Polsce”, realizowane przez Centrum Edukacji Obywatelskiej i skierowane do uczniów i nauczycieli szkół gimnazjalnych oraz ponadgimnazjalnych; zob. P. Filipkowski, Historia mówiona i wojna. Doświadczenie obozu koncentracyjnego w perspektywie narracji biograficznych, Wrocław 2010, s. 35; I. Lewandowska, Oral history we wspótczesnej Polsce - badania, projekty, stowarzyszenia, „Wrocławski Rocznik Historii Mówionej” 2011, nr 1, s. 92-93. 
cunek, dociekliwość czy taktowność ${ }^{20}$. Uczestnictwo w projekcie pozwala także kształtować określone kompetencje poznawcze - osoby nagrywające i opracowujące relacje, stykając się z ustną narracją, doświadczają rozdźwięku między różnymi typami dyskursów (tj. między znanym ze szkolnych podręczników i aspirującym do obiektywizmu „dyskursem historii”, utożsamianym z modernizmem i scjentyzmem, a subiektywnym „dyskursem pamięci”, identyfikowanym z ponowoczesnością, humanizmem i emancypacją) ${ }^{21}$. Rozdźwięk ten może być obserwowany jednocześnie w trzech wymiarach: na płaszczyźnie ustalania faktów (tj. krytycznego tworzenia dokumentacji), na płaszczyźnie różnicy między sferą słowa mówionego a posiadającą wyższy status sferą słowa pisanego, a także na płaszczyźnie wyjaśniania przyczyn wydarzeń oraz poszukiwania motywów i racji działania22. Będąca efektem doświadczania tego rodzaju rozdźwięków indywidualna refleksja oparta na obserwacji, analizie procesów społecznego komunikowania się i kształtowania narracji historycznych, może prowadzić do rozwijania kompetencji w sferze samodzielnego myślenia i krytycznego podejścia do różnego rodzaju źródeł.

\subsection{Oferta edukacyjna}

Począwszy od lat siedemdziesiątych i osiemdziesiątych XX wieku, wraz ze wzmożonym zainteresowaniem historią mówioną na gruncie akademickim, relacje i wspomnienia świadków wydarzeń historycznych coraz częściej stają się częścią ekspozycji historycznych przygotowywanych przez muzea i różnego rodzaju instytucje. Zasoby relacji zgromadzone przy aktywnym współudziale członków społeczności są przetwarzane i udostępniane, stając się elementem współtworzącym - niejako „wtórnie” - zasoby pamięci indywidualnej i grupowej, współkształtując tym samym lokalne środowisko edukacyjno-wychowawcze.

20 Por. W. Theiss, Między Wegrowem a Caracas. O korespondencyjnym dialogu w poznawaniu polsko-żydowskiej przeszłości, [w:] Pamięć, Miejsce, Obecność. Wspótczesne refleksje nad kulturq i ich implikacje pedagogiczne, red. J.P. Hudzik, J. Mizińska, Lublin 1997, s. 240.

21 Por. F. Ankersmit, Pamiętając Holocaust: żałoba i melancholia, [w:] Frank Ankersmit. Narracja..., s. 404, 4.06.

22 P. Ricoeur, op. cit., s. 29-30; zob. też E. Domańska, Wprowadzenie: Pamięć, etyka..., S. 16. 
Źródeł obecności historii mówionej na gruncie wystawienniczym szukać należy z jednej strony w pogłębiającym się zainteresowaniu historią $\mathrm{XX}$ wieku, z drugiej zaś - w rozwoju technologii, pozwalającym na coraz łatwiejsze konstruowanie narracji muzealnej, z wykorzystaniem zasobów relacji, traktowanych jako swoiste, „niematerialne obiekty”23. Jednocześnie, znaczącą rolę w tym procesie odgrywają przemiany zachodzące na gruncie postrzegania statusu oraz społecznej, kulturotwórczej i edukacyjnej roli muzeów i innych instytucji oraz wynikające z nich przeobrażenia dotyczące sposobu myślenia o formach konstruowania przestrzeni wystawienniczej. Podkreślane na gruncie teoretycznym znaczenie tego rodzaju placówek, mających służyć zmianie społecznej nie tyle przez dostarczanie wiedzy historycznej, co poprzez wspieranie rozwoju i wzrostu samoświadomości odbiorców, a także kształtowanie kompetencji umożliwiających im dalsze samokształcenie, przyniosło nowe ujęcia jeśli chodzi o sposób myślenia o budowaniu relacji między ekspozycją a zwiedzającym. Przyczyniło się to m.in. do powstania koncepcji ekspozycji funkcjonującej jako przestrzeń komunikacji i aktywnej wymiany doświadczeń, angażującej odbiorców w proces współkształtowania narracji. Autorytarne upowszechnianie wiedzy faktograficznej z wykorzystaniem transmisyjnego, zdominowanego przez nadawcę modelu komunikacji, miało w nich zostać zastąpione podejściem ukierunkowanym na konstruowanie partycypacyjnych, procesualnych form kontaktu z odbiorcą. W tego typu ekspozycji wiedza ogólna miała być integrowana z wiedzą opartą na codziennych doświadczeniach jednostek, przekazywanie zaś informacji za pośrednictwem eksponatów, traktowanych jako obiektywne formy reprezentacji wydarzeń z przeszłości, miało ustępować działaniom angażującym - poprzez odwołanie się do indywidualnych wypowiedzi świadków historii - wyobraźnię i emocje widzów ${ }^{24}$. Wskazując na potrzebę odchodzenia w dyskursie wystawienniczym od przekazywania „twardej wiedzy historycznej” w kontekście „wielkich narracji”, na rzecz budowania przestrzeni doświadczenia i partycypacji oraz nadawania wydarzeniom „ludzkiego wymiaru”, twórcy i kuratorzy wystaw podkreślali wartość „teatralizacji" ekspozycji i konieczność otwarcia się na wykorzystanie nowych

23 A. Ziębińska-Witek, Historia w muzeach. Studium ekspozycji Holokaustu, Lublin 2011, s. 249.

24 Ibidem, s. 29-39. 
mediów oraz materiałów audiowizualnych. W tej performatywnej, partycypacyjnej perspektywie, ekspozycja sama stawała się medium, a sposób jej odbioru zależny był od aktywności zwiedzającego, który wchodząc w interakcje z prezentowanymi obiektami miał możliwość bardziej zaangażowanego uczestnictwa, tak wyraźnie postulowanego na gruncie teorii pedagogicznych ${ }^{25}$.

We współczesnym wystawiennictwie wskazać można wiele strategii posługiwania się historią mówioną. Relacje prezentowane w formie audio, wideo lub w formie tekstu, mogą odnosić się do określonych zagadnień tematycznych, uzupełniając pokazywane na wystawie fotografie, mapy czy dokumenty, mogą być też traktowane jako samodzielne obiekty tworzące odrębną narrację i luźno korespondujące z pozostałymi elementami ekspozycji. W niektórych muzeach historie mówione są prezentowane przy osobnych stanowiskach lub w salach (kinowych, audialnych), gdzie żadne inne bodźce nie odwracają uwagi odbiorcy. W praktyce w jednej ekspozycji łączone są zazwyczaj różne strategie posługiwania się historią mówioną, a zróżnicowanie form prezentacji relacji sprawia, iż pełnią one różnego rodzaju funkcje: pojedyncza relacja może być reprezentatywna dla losów większej grupy osób czy wydarzeń; większy zbiór relacji może być zaprezentowany w celu ukazania w szerszej perspektywie określonych zagadnień; możliwe jest też potraktowanie wspomnień jako swoistego tekstu i odwołanie się do narzędzi analitycznych wykształconych m.in. na gruncie socjologii czy badań literackich w celu przeanalizowania, w jaki sposób narrator opisuje wydarzenia z przeszłości, jaki nadaje im sens oraz jak postrzega ich znaczenie w szerszym kontekście własnej biografii, historii lokalnej czy historii powszechnej. Relacje mogą też być poddawane pogłębionej analizie rekonstrukcyjnej, pozwalającej na odczytywanie określonych wzorców zachowań czy przebiegu wydarzeń, jednak tego typu działania nie są często podejmowane w praktyce ${ }^{26}$.

Wykorzystanie historii mówionych w przestrzeni wystawienniczej niesie znaczący potencjał edukacyjny, jak też wiele problemów - zarówno dla organizatorów, jak i dla zwiedzających. Ich źródłem jest m.in. wybór fragmentów relacji dokonywany przez twórców i kuratorów wystaw,

25 Ibidem, s. 40-50, s. 262.

26 P. Thompson, The Voice of the Past. Oral History, Oxford University Press 20oo, S. $269-272$. 
kierujących się zazwyczaj w większym stopniu potrzebą forsowania określonych tez historycznych, politycznych czy społecznych, niż dążeniem do zachowania spójności wypowiedzi. Może dochodzić tu do zerwania ciągłości opowieści: rzeczywista historia narratora, jego punkt widzenia i sposób rozumienia wydarzeń zacierają się, a wyrwanie fragmentów relacji z pierwotnego kontekstu nadaje im często odmienny sens i znaczenie, co prowadzić może do przeinaczania - m.in. w imię poprawności politycznej - pierwotnych intencji narratora. Odrębnym źródłem trudności są także kwestie związane z przyjęciem określonej strategii prezentowania relacji na wystawie, od której zależy siła oddziaływania i sposób interpretowania całej ekspozycji przez odbiorców.

\subsection{Działania artystyczne}

Zasoby relacji mówionych mogą stać się także tworzywem lub strategią komunikacyjną stosowaną w takich projektach artystycznych, jak spektakle, performance czy environment, realizowanych w przestrzeni miejskiej lub w zamkniętej przestrzeni teatralnej czy wystawienniczej. Przedsięwzięcia tego rodzaju wpisują się w szeroko rozumiany ruch uspołeczniania sztuki, rozwijający się w atmosferze debaty i kontestacji nie tylko estetycznej, ale też społeczno-politycznej, wyrastającej z przekonania, iż artysta powinien być także animatorem kultury, a jego zadaniem jest wspieranie społeczności lokalnej w wyrażaniu jej potrzeb i problemów. Postulaty formułowane w latach 30. XX wieku i wskazujące na potrzebę przywrócenia znaczenia teatru jako istotnego elementu życia społecznego, przejęte przez awangardę drugiej połowy stulecia, uobecniły się w działalności amerykańskich i europejskich teatrów alternatywnych, a także w pracy wielu indywidualnych twórców. W projektach artystycznych realizowanych w przestrzeni miejskiej przez Petera Schumana i jego Bread and Puppet Theatre, w wykreowaną przestrzeń o charakterze environment, wpisywane były wspomnienia ofiar wojny w Wietnamie. Głosy ludzkie - ledwo słyszalne szepty, współtworzyły „dźwiękową scenografię”, będąc konstytutywną częścią dzieła, a zarazem elementem umożliwiającym nawiązanie emocjonalnego kontaktu między artystami a widzami. Historie mówione pojawiły się też w cyklu przedstawień pod wspólnym tytułem Dziedzictwo Kaina odgrywanych przez The Living Theater w czasie artystycznej wyprawy do Brazylii, jaką grupa odbyła na początku lat siedemdziesiątych XX wieku. W przedstawieniach odgrywanych w kolejnych favelach i przygotowywanych przy współudziale lokalnej społeczności, wykorzystywane były fragmenty wspo- 
mnień mieszkańców. Celem projektu, noszącego znamiona pracy społeczno-edukacyjnej, było upodmiotowienie i aktywizowanie odbiorców, a także zachęcanie ich do samodzielnego rozwiązywania własnych problemów.

Wprowadzenie relacji mówionych do sfery działań artystycznych dokonało się także za pośrednictwem europejskiego i amerykańskiego teatru dokumentalnego, zmierzającego do twórczej rekonstrukcji historii. Twórcy tego rodzaju dzieł, operując historiami mówionymi, a także innymi materiałami biograficznymi (listy, fotografie, akta sądowe itp.), w sposób twórczy dokonywali reinterpretacji wydarzeń z przeszłości. Proponując subiektywną perspektywę rozumienia dynamiki procesów historycznych, manipulowali materiałem dokumentalnym, a współtworzące fabułę wspomnienia służyły przekazaniu określonych tez społecznych czy politycznych ${ }^{27}$.

\section{3. "Historia Mówiona Miasta Lublina" w Ośrodku Brama Grodzka - Teatr NN}

Począwszy od 1998 r., w ramach realizowanego przez Ośrodek „Brama Grodzka - Teatr NN” projektu „Historia Mówiona Miasta Lublina” nagrywane są relacje mieszkańców dotyczące okresu międzywojennego. Projekt ten stanowi część programu „Wielka Księga Miasta”, którego celem jest gromadzenie, opracowywane i udostępniane różnego rodzaju materiałów (tekstów literackich, fotografii archiwalnych, wspomnień oraz dokumentów osobistych). Zgromadzone materiały są wykorzystywane przy realizacji różnego rodzaju projektów o charakterze artystycznym i animacyjno-edukacyjnym, odnoszących się do dziejów Lublina, ze szczególnym uwzględnieniem dawnego, polsko-żydowskiego charakteru miasta.

\subsection{Tworzenie archiwum relacji}

Realizacja projektu „Historia Mówiona Miasta Lublina” wymagała wypracowania autorskiej procedury obejmującej zasady przeprowadzania, przepisywania, opracowywania i archiwizowania relacji, uwzględniającej poznawcze i edukacyjne cele programu „Wielka Księga Miasta”. Opracowany został standardowy kwestionariusz, mający stanowić punkt wyjścia do prowadzenia wywiadu, pozwalający jednak na nadanie każdej rozmowie 
indywidualnego charakteru. Powstały także wzory kart inwentaryzacyjnych i innych dokumentów oraz pism, a także różnego rodzaju teksty instruktażowe dla osób biorących udział w projekcie. Do nagrywania wywiadów angażowani byli pracownicy i współpracownicy Ośrodka, a także wolontariusze, uczniowie i studenci po uprzednim przeszkoleniu. Poszukiwanie osób pamiętających przedwojenny Lublin odbywało się najczęściej metodą „śnieżnej kuli” - osoby biorące udział w projekcie szukały potencjalnych rozmówców, najpierw wśród własnej rodziny i znajomych, a następnie wśród dalszych osób zaprzyjaźnionych lub spokrewnionych z rozmówcami. W późniejszym okresie nagrywane były także wywiady z przedwojennymi mieszkańcami Lublina odwiedzającymi Ośrodek w celu zwiedzenia wystawy „Wielka Księga Miasta” i „Portret Miejsca”.

W pierwszej części wywiadu rozmówcy byli proszeni o skrótowe przedstawienie swojej biografii z uwzględnieniem informacji o rodzinie, miejscu zamieszkania, przebiegu edukacji i pracy zawodowej. W drugiej części pojawiały się pytania dotyczące Lublina w okresie międzywojennym w perspektywie osobistych wspomnień związanych z domem rodzinnym, szkołą i sposobami spędzania wolnego czasu, a także pytania dotyczące przestrzeni miejskiej, tj. wyglądu poszczególnych ulic i obiektów. Osobną część wywiadu stanowiły pytania o kontakty i relacje z przedstawicielami innych grup etnicznych i wyznaniowych, w tym - zwłaszcza - o lubelską dzielnicę żydowską na Podzamczu i o jej przedwojennych mieszkańców. W wielu wypadkach ważnym elementem relacji były wspomnienia z okresu okupacji, w tym - kwestie dotyczące likwidacji getta na Podzamczu i zagłady lubelskich Żydów ${ }^{28}$.

Nagrane relacje były przepisywane, opracowywane i archiwizowane, a następnie wprowadzane (w formie tekstów i dźwięków), wraz z opracowaniami teoretycznymi i materiałami edukacyjnymi, do udostępnianej drogą internetową bazy danych, stanowiącej część prowadzonego przez Ośrodek portalu. Równolegle organizowane były szkolenia i warsztaty historii mówionej dla uczniów, studentów, nauczycieli i animatorów, istniała też możliwość realizacji indywidualnych projektów polegających na nagrywaniu relacji, m.in. w ramach praktyk studenckich czy staży podyplomowych 29 .

28 M. Kubiszyn, op. cit., s. 213.

29 Ibidem, s. 212-215. 
Stopniowo projekt „Historia Mówiona Miasta Lublina” rozwijał się i wzbogacał o kolejne inicjatywy, poszerzając - zarówno pod względem terytorialnym, jak i czasowym - tematyczne obszary odniesienia. W latach 1999-2002 realizowany był projekt „Krawiecka 41”, którego istotnym elementem było zbieranie relacji dotyczących jednej spośród nieistniejących już kamienic z terenu dawnej dzielnicy żydowskiej. Począwszy od 2002 r., wraz z realizacją programu „Zapomniana Przeszłość - Wielokulturowe Tradycje Lubelszczyzny”, Ośrodek rozpoczął gromadzenie relacji dotyczących poszczególnych miejscowości regionu lubelskiego w okresie międzywojennym. W kolejnych latach zrealizowano wiele innych projektów, w ramach których nagrywane były wspomnienia dotyczące Lublina w okresie powojennym, ze szczególnym uwzględnieniem takich zagadnień, jak m.in. strajki w Lublinie i regionie w lipcu $1980 \mathrm{r}$. (projekt „Lubelski Lipiec”, 2005), wydarzenia związane z powstaniem Solidarności (projekt „wagon.lublin.pl”, 2005), wydarzenia z okresu stanu wojennego (projekt „Stan Wojenny. 25 lat później”, 2006), niezależny ruch wydawniczy w latach 1977-1989 (projekt „Siła Wolnego Słowa”, 2007), czy historia lubelskiej Grupy Zamek (projekt „Grupa Zamek”, 2007) ${ }^{30}$. Nagrywanie relacji mówionych dotyczących pomocy udzielanej Żydom w okresie okupacji niemieckiej było ważnym elementem realizowanego od 2002 r. projektu „Światła w ciemności. Sprawiedliwi wśród Narodów Świata”31, a od 2011 r., w ramach projektu „Miłosz w Lublinie”, Ośrodek zbiera wspomnienia dotyczące noblisty ${ }^{32}$. Obecnie (2012 r.) w archiwum Ośrodka znajdują się wspomnienia ponad 900 osób, łącznie ok. 2500 godzin rozmów nagranych w technice cyfrowej (audio i wideo).

W trakcie realizacji projektu „Historia Mówiona” powstało wiele różnego rodzaju tekstów odnoszących się zarówno do samego projektu, jak i do historii mówionej analizowanej jako narzędzie w pracy animacyjnej i edukacyjnej, a także wiele różnego rodzaju publikacji ${ }^{33}$,

30 Szczegółowe informacje i opisy projektów na: http://tnn.pl/k_281_m_3.html (dostęp: 21 VII 2012 r.).

31 Światła w ciemności. Sprawiedliwi wśród Narodów Świata. Relacje, red. A. Dąbrowska, Lublin 2008.

32 Zob.: http://teatrnn.pl/leksykon/projekt/milosz_w_lublinie (dostęp: 21 VII 2012 r.).

33 Zob. m.in.: M. Kubiszyn, Portret ulic, „Karta” 2ooo, nr 31, s. 16-39; eadem, Historia (nie)mówiona, „Scriptores” 2003, nr 2, s. 91-105; Światła w ciemności - Sprawiedliwi wśród Narodów Świata: relacje historii mówionej w działaniach edukacyjnych, 
artykułów prasowych ${ }^{34}$, reportaży radiowych ${ }^{35}$ oraz filmów dokumentalnych ${ }^{36}$, w których wykorzystane były relacje zgromadzone w archiwum Ośrodka. Przygotowanych zostało także kilka scenariuszy lekcji dla szkół ponadpodstawowych, z wykorzystaniem relacji mówionych. Scenariusze te wraz z materiałami dla nauczycieli dostępne są na stronie internetowej Ośrodka ${ }^{37}$, a także w publikacjach ${ }^{38}$.

red. M. Baum-Gruszowska, D. Majuk Dominika, Lublin 2009; Ścieżki Pamięci. Żydowskie miasto w Lublinie - losy, miejsca, historia, red. J. Bojarski, Lublin-Rishon Le Zion 2001; J. Grzesik, Zagłada Żydów (1939-1945), Lublin 2008; Skrawki pamięci. Wielokulturowa przeszłość Ziemi Wojsławickiej we wspomnieniach jej mieszkańców, red. E. Majuk, Wojsławice 2005.

34 Zob.: http://tnn.pl/k_323_m_3.html (dostęp: 21 VII 2012 r.).

35 Zob. m.in.: reportaż Duchy Kurowa, reż. Mariusz Kamiński (Radio Lublin, 2008 r.), gdzie wykorzystane zostały fragmenty relacji Ruth Goldberg - przedwojennej mieszkanki Kurowa, zarejestrowanej w ramach projektu „Lubliniacy. W poszukiwaniu Lublina w Izraelu"; audycja Agaty Koss-Dybały (Radio Lublin, 2008 r.) poświęcona obchodom Święta 3 Maja w PRL; audycja Strefa Stowa, reż. Agnieszka Lubowiecka i Wioleta Matela (Akademickie Radio Centrum, Lublin, 2008 r.), poświęcona programowi „Historia Mówiona” Ośrodka Brama Grodzka - Teatr NN, w której wykorzystano fragmenty relacji Marianny Turek ze zbiorów Ośrodka; audycja Historia bez patyny, reż. Marta Grydniewska (Radio Lublin, 2008 r.), poświęcona likwidacji getta lubelskiego na Podzamczu, w której wykorzystane zostały wspomnienia lubelskich Żydów zarejestrowane w ramach projektu „Lubliniacy. W poszukiwaniu Lublina w Izraelu"; reportaż Ania z Lublina, reż. Agata Koss-Dybała (Radio Lublin, 2008 r.), poświęcony pochodzącej z Lublina pisarce Annie Szterfinkiel-Langfus, i wykorzystujący fragmenty relacji Henryki Heinsdorff, siostrzenicy Anny Langfus, nagranej w ramach projektu „Lubliniacy; za: http://tnn.pl/k_298_m_3.html (dostęp: 21 VII 2012 r.).

36 Zob. m.in.: Światta w ciemności - Sprawiedliwi wśród Narodów Świata, reż. Marta Pietrasiewicz, TVP Lublin 2008; Święto historii mówionej (fragment programu Afisz Kulturalny), reż. Natasza Ziółkowska-Kurczuk, TVP Lublin 2008; Errata do biografii Anna Langfus, reż. Robert Kaczmarek, TVP 1, 2007; Drukarze, reż. Henryk Urbanek, TVP 1, 2006; 13 grudnia - tak byto..., reż. Leszek Wiśniewski, TVP Lublin 20o6; za: http://tnn.pl/k_689_m_3.html (dostęp: 21 VII 2012 r.).

37 Zob.: http://tnn.pl/k_309_m_3.html (dostęp: 21 VII 2012 r.).

38 Część scenariuszy zostało opublikowanych w podręczniku dla nauczycieli wydanym przez Ośrodek Brama Grodzka we współpracy z Zakładem Kultury i Historii Żydów UMCS oraz amerykańską fundację Projectguggenheim, zob.: M. Kubiszyn, G. Żuk, M. Adamczyk-Garbowska, Dziedzictwo Kulturowe Żydów na Lubelszczyźnie. Materiaty dla nauczycieli, Lublin 2003, s. 8-19, 31-42, 47, 57-66. 
Począwszy od 1998 r. gromadzone w Ośrodku relacje były wykorzystywane w różnego rodzaju działaniach animacyjnych i artystycznych, a zwłaszcza w projektach odwołujących się do dziejów Żydów lubelskich. Dzięki wspomnieniom, w których znalazły odzwierciedlenie osobiste i rodzinne losy mieszkańców splecione z historią miasta, możliwa stała się częściowa rekonstrukcja pewnych fragmentów struktury urbanistycznej sprzed 1939 r., zniszczonej bądź znacząco przekształconej w trakcie działań wojennych i po wojnie. Podjęta została także próba odtworzenia elementów multisensorycznego krajobrazu przedwojennego Lublina, obejmującego kolory i dźwięki ${ }^{39}$.

Udostępniana od maja 1999 do 2010 r. multimedialna wystawa „Portret Miejsca" wprowadziła historię mówioną w niekonwencjonalnie zaaranżowaną przestrzeń, przekraczającą estetyczne i strukturalne granice między spektaklem teatralnym a ekspozycją. Głównym elementem budującym scenografię była konstrukcja złożona z wielu zawieszonych na ścianach i połączonych ze sobą płytkich skrzyń, w których (i na których) prezentowano fotografie (w formie odbitek i slajdów), ukazujące ulice i poszczególne obiekty dawnego zespołu staromiejskiego. W drewnianą konstrukcję wmontowane zostały także głośniki, z których słychać było wielowątkową opowieść dotyczącą przedwojennego Lublina skomponowaną z fragmentów kilku relacji mówionych. Przeplatała się ona z przygotowaną specjalnie na potrzeby wystawy kompozycją, będącą rekonstrukcją domniemanego „krajobrazu dźwiękowego” tej części miasta ${ }^{40}$.

Wpisanie wystawy we wnętrza Bramy Grodzkiej, tworzone przez ciągi wąskich korytarzy łączących amfiladowo ułożone pomieszczenia, czyniło z jej zwiedzania symboliczny spacer po uliczkach i zaułkach przedwojennego starego miasta i dzielnicy żydowskiej. Dzięki wielopłaszczyznowej warstwie dźwiękowej i obrazowej, a także dzięki przeplataniu różnych wątków i łączeniu wielu form mówienia o mieście, wystawa przybrała postać subiektywnej, poetyckiej opowieści, mającej niewiele wspólnego z tradycyjną ekspozycją o charakterze historycznym.

39 Por. Yi-Fu Tuan, Przestrzeń i miejsce, Warszawa 1987, s. 27-29, zob. też S. Bernat, Krajobraz dźwiękowy miasta Lublina, [w:] Krajobraz kulturowy - idee, problemy, wyzwania, red. U. Myga-Piątek, Sosnowiec 2001, s. 11-12.

40 M. Kubiszyn, Edukacja wielokulturowa..., s. 215-220. 
Podobny sposób myślenia o konstruowaniu przestrzeni wystawienniczej i budowaniu ekspozycji z wykorzystaniem materiałów dokumentalnych, obecny jest także w przygotowanej przez Ośrodek i prezentowanej od maja 2003 r. w baraku nr 53 na terenie byłego obozu na Majdanku, wystawie „Elementarz”. Przywołując losy czworga dzieci różnych narodowości (dziecko polskie, białoruskie i dwoje dzieci żydowskich, spośród których troje przetrwało okupację), w sposób symboliczny odnosi się ona do przeżyć najmłodszych więźniów obozu. Ekspozycja podzielona została na dwie części reprezentujące - poprzez umieszczone w ich przestrzeni obiekty świat dzieciństwa przeżywanego w warunkach pokoju i świat egzystencji obozowej, ukazanej symbolicznie przez kluczowe pojęcia, współtworzące swoisty „elementarz obozu” (transport, komora gazowa, głód itp.).

W części pierwszej znajduje się tablica szkolna z wypisanymi imionami dzieci - bohaterów wystawy. Leżą tu także reprodukowane na płótnie przedwojenne elementarze w języku polskim, białoruskim i jidysz, a z głośników dobiega gwar dziecięcych głosów zarejestrowanych na potrzeby ekspozycji w jednej z lubelskich szkół. W części odnoszącej się do życia w obozie znajduje się szkielet wagonu (będący symbolem Zagłady) oraz betonowe studnie. Z wnętrza trzech studni słychać opowieści byłych więźniów, którzy przebywali na Majdanku jako dzieci, jedna pozostaje milcząca, gdyż dziecko, którego losy reprezentuje zginęło w obozie. Fragmenty wspomnień, odnoszące się do doświadczeń obozowych zostały także wypalone na glinianych tablicach umieszczonych wzdłuż ścian baraku.

Podobnie jak omówiona powyżej wystawa „Portret Miejsca”, ekspozycja pokazywana na Majdanku ma charakter audiowizualnej instalacji - scenografii skonstruowanej wokół historii mówionych i innych dźwięków, a także wspomnień prezentowanych w formie tekstów. Wykorzystane zostały również slajdy - reprodukcje fotografii przedstawiających twarze dzieci, znalezionych na terenie Majdanka po likwidacji obozu. Relacje oraz zdjęcia użyto tu jednak w inny sposób i nie służą konstruowaniu spójnej narracji czy tworzeniu reprezentacji rzeczywistości, a niełatwy w odbiorze przekaz budowany jest poprzez świadectwa indywidualnych emocji i przeżyć ${ }^{41}$.

41 Obszerniej na temat wystawy „Elementarz”, zob. A. Ziębińska-Witek, op. cit., s. 204214; zob. też: M. Grudzińska, Elementarz, „Obyczaje” 2004, nr 16, s. 34-38; B. Jesionek-Biskupska, E. Surtel, Uczniowskie „elementarze”. Scenariusz zajęć w gimnazjum, „Zeszyty Szkolne” 2003, nr 4, s. 55-58. 
Relacje mówione znajdujące się w archiwum Ośrodka są też często wykorzystywane w realizowanych od 2000 r. Misteriach Pamięci. Usytuowane między plenerowym działaniem parateatralnym i artystycznym environment, akcje te mają tworzyć warunki do odczytywania i reinterpretowania przez mieszkańców Lublina znaczeń związanych z przestrzenią miasta, w kontekście jego historii. Bezpośrednią inspiracją do powstania niektórych Misteriów (m.in. Jedna Ziemia, Dwie Świątynie, Poemat o Miejscu, Misterium Światła i Ciemności) było dążenie do odniesienia się - poprzez działanie artystyczne - do pustki po nieistniejącej dzielnicy żydowskiej oraz do materialnego i niematerialnego dziedzictwa zgładzonej społeczności. Pozostałe Misteria Ośrodka odwoływały się do szerszej problematyki związanej z Zagładą (Dzień Pięciu Modlitw na Majdanku, Pamięć Sprawiedliwych - Pamięć Światta) oraz innych zagadnień dotyczących szeroko rozumianego dziedzictwa społeczno-kulturowego Lublina (Misterium Druku i Papieru, Misterium Dzwonu św. Michała) ${ }^{42}$.

Choć działania te nie były jednolite w formie i odnosiły się do różnych zagadnień, w większości przypadków sposób budowania strony formalnej Misteriów wynikał z dążenia do wykreowania sytuacji artystycznej, w której konkretne miejsce „samo opowiada swoją historię”, a jednocześnie przekształcane jest - poprzez działanie twórcze - w symboliczną „przestrzeń upamiętniania”. Koncepcja ta, szczególnie w przypadku Misteriów tematycznie związanych z nieistniejącą dzielnicą żydowską i zagładą lubelskich Żydów, realizowana była poprzez nakładanie na infrastrukturę urbanistyczną elementów scenografii oraz instalowanie urządzeń technicznych umożliwiających odtwarzanie dźwięków (a czasem także prezentację obrazów), mających służyć metaforycznemu przywoływaniu przeszłości. Historie mówione i wygłaszane na żywo opowieści świadków stanowiły ważny element omawianej grupy Misteriów, kształtując narrację poszczególnych wydarzeń.

Misterium Jedna Ziemia Dwie Świątynie zrealizowane przez Ośrodek we wrześniu 2000 r., rozegrało się w przestrzeni obejmującej część starego miasta (Plac po Farze, gdzie dawniej znajdował się kościół św. Michała), ulicę Grodzką i Bramę Grodzką oraz teren dawnej dzielnicy żydowskiej, tj. obecny Plac Zamkowy i fragment Alei Tysiąclecia, gdzie niegdyś 
stała synagoga Maharszala. W przestrzeni tej wyodrębnione zostały zarysy fundamentów nieistniejącej fary i synagogi oraz linia łączących je dawniej ulic. Symboliczne pojednanie dwóch światów należących niegdyś do dwóch odrębnych obszarów kulturowych dokonało się poprzez stworzenie drogi - korytarza, wyznaczonego w przestrzeni przez dwa szpalery ludzi - mieszkańców Lublina trzymających świece, między którymi stali Żydzi ocaleni z Holokaustu oraz Sprawiedliwi wśród Narodów Świata. Ważnym elementem akcji było wykopanie, przeniesienie i wymieszanie ziemi z miejsc, gdzie dawniej stały dwie świątynie. W wymieszanej ziemi zasadzone zostały dwa krzewy winorośli symbolizujące spotkanie i pojednanie. Zasadniczą narrację Misterium tworzyły wygłaszane na żywo opowieści Ocalonych i Sprawiedliwych, które - dzięki nagłośnieniu - były słyszalne dla wszystkich uczestników wydarzenia.

Misterium Poemat o Miejscu zrealizowane w październiku 2002 r. na lubelskim Podzamczu, przywoływało nieistniejącą dzielnicę żydowską, jak też historię lubelskiego zamku pełniącego przez wiele lat funkcję hitlerowskiego, a następnie stalinowskiego więzienia. Wizualno-dźwiękowa scenografia budowana była przez snopy światła rzucane pionowo w górę przez reflektory umieszczone w otwartych studzienkach kanalizacyjnych oraz opowieści byłych więźniów zamku nałożone na wspomnienia dotyczące dzielnicy żydowskiej i jej unicestwienia, dobywające się z głośników umieszczonych w studzienkach razem z reflektorami. Uczestnicy Misterium podążali w ciemności trasą wyznaczaną przez zapalające się kolejno reflektory, prowadzącą ich w kierunku miejsca, gdzie dawniej znajdowała się synagoga Maharszala. Aby usłyszeć rozbrzmiewające w mroku i dobywające się spod powierzchni ziemi opowieści świadków, uczestnicy Misterium pochylali się nad każdą studzienką, okazując nie tylko pokorę, ale też odwagę skonfrontowania się z bolesnymi wydarzeniami z przeszłości.

Zrealizowane w listopadzie $2000 \mathrm{r}$, we współpracy z Państwowym Muzeum na Majdanku Misterium Dzień Pięciu Modlitw, rozegrane zostało na terenie byłego obozu i było poświęcone więźniom różnych wyznań i narodowości, którzy tam zginęli. W Misterium uczestniczyła grupa byłych więźniów Majdanka, duchowni pięciu wyznań i religii (katolicy, muzułmanie, prawosławni, protestanci, Żydzi) oraz mieszkańcy Lublina. Scenariusz Misterium zakładał przejście przez wszystkich uczestników kilkuhektarowej przestrzeni byłego obozu trasą prowadzącą przez plac selekcyjny, plac apelowy na III polu, aż do krematorium, która w sposób symboliczny odnosiła się do losów więzionych tu niegdyś osób. W czasie 
tego przemarszu, w wybranych miejscach odbyły się modlitwy prowa-

dzone przez duchownych różnych wyznań i religii, co miało podkreślać ponadreligijny wymiar obozowych doświadczeń i uniwersalny charakter ludzkiego cierpienia.

Warstwę dźwiękową Misterium tworzyło kilka budowanych równolegle i momentami przenikających się narracji. Pierwszą warstwę stanowiły odtwarzane z taśm wspomnienia dotyczące obozu. Z nałożonych na siebie fragmentów wypowiedzi byłych więźniów tworzył się swoisty „chór”, z którego co pewien czas wyłaniał się pojedynczy głos słyszalny na tle pozostałych. Drugą warstwę tworzyły głosy biorących udział w Misterium byłych więźniów, odczytujących na żywo fragmenty wspomnień, które - dzięki głośnikom zainstalowanym wzdłuż trasy przemarszu - rozbrzmiewały w przestrzeni obozu. Trzecią warstwę stanowiły modlitwy wygłaszane przez duchownych, czwartą zaś - wypowiedzi dwóch narratorów prowadzących całe wydarzenie.

Przywołane Misteria nie opisują i nie wyjaśniają wydarzeń z przeszłości, lecz uobecniając to, co nieobecne, tworzą artystyczne, metaforyczne substytuty. Porzucanie bezosobowego, intersubiektywnego języka narracji historycznej na rzecz odwołania się do wspomnień i relacji odzwierciedlających jednostkowe doświadczenia, służyć ma humanizacji i indywidualizacji opowieści, wyrażając jednocześnie przeświadczenie, iż poprzez tego rodzaju wypowiedź w najpełniejszy sposób można zbliżyć się do prawdy, rozumianej jako subiektywna prawda doświadczenia jednostki.

W Misteriach Pamięci, dążenie do uobecnienia przeszłości wiąże się z wyraźnym poczuciem współodpowiedzialności za kształtowanie obrazu przeszłości, co nadaje realizowanym działaniom wyraźny wymiar pracy edukacyjnej. Osadzenie działań w przestrzeni miejskiej służy tu nie tylko realizacji określonych celów artystycznych, ale przede wszystkim przybliżeniu określonej problematyki społeczności lokalnej. Rezygnacji z budowania uogólnionej narracji służącej prostemu przekazywaniu określonej wiedzy o przeszłości, towarzyszy zwrot ku poetyckim środkom wyrazu, poszukiwanie odrębnych rozwiązań estetycznych i formalnych, a także odwołanie się do kategorii etycznych (wina, zadośćuczynienie, odpowiedzialność) oraz do kategorii powstałych na gruncie psychoanalizy (trauma, żałoba, melancholia, przepracowanie). Wykorzystanie relacji mówionych, poprzez które możliwe jest porządkowanie istniejących narracji, pozwala na (re)interpretację wyobrażeń o wydarzeniach z przeszłości oraz lepsze zrozumienie ich znaczenia dla teraźniejszości. 


\section{Wnioski dla teorii i praktyki}

Na gruncie teoretycznym, edukacyjno-wychowawczy potencjał projektów odwołujących się do historii mówionej wzmiankowany jest najczęściej w odniesieniu do możliwości zgłębiania tą drogą społecznego i historycznego doświadczenia grup i osób. Przyjmuje się, iż sięganie poza zasoby własnego doświadczenia i pamięci, umożliwia jednostce budowanie emocjonalnych związków z przeszłością, a także rozwijanie więzi z innymi członkami zbiorowości ${ }^{43}$. Za pośrednictwem historii mówionej możliwe jest też poznawanie norm i wartości kluczowych w procesie budowania tożsamości i warunkujących pełniejszą partycypację jednostki w życiu społecznym grupy. Zarówno samodzielne nagrywanie i opracowywanie relacji, jak i kontakt z tego rodzaju materiałem za pośrednictwem różnego rodzaju publikacji, wystaw i działań artystycznych, wspiera proces zdobywania wiedzy historycznej i pozwala na lepsze rozumienie mechanizmów społecznych kierujących postępowaniem ludzi, wpływając tym samym na zachowanie jednostki w teraźniejszości.

W wielu realizowanych obecnie w Polsce projektach społecznościowych, odwołujących się - poprzez historię mówioną - do zasobów grupowej i jednostkowej pamięci, historia mówiona postrzegana jest jako źródło wiedzy o przeszłości i ludzkiej kondycji, a także jako narzędzie działania społecznego odgrywające znaczącą rolę w procesie edukacyjno-wychowawczym. Ukazywanie wydarzeń z przeszłości z oddolnej perspektywy, w kategoriach bliskich jednostce, odnoszenie się do problematyki lokalnej z uwzględnieniem związków i interakcji między ludźmi a miejscami, tworzy warunki do rozwoju postaw prośrodowiskowych, wspierając kształtowanie tożsamości i budowanie więzi z innymi członkami grupy.

Wspomagając procesy (re-)interpretowania historii i odkrywania tożsamości na poziomie jednostkowym i zbiorowym, historia mówiona może wspierać procesy demokratyzacji i budowania społeczeństwa obywatelskiego, a także osiągania podmiotowości przez społeczności lokalne $^{44}$. W świetle teorii pedagogiki społecznej, projekty dokumentalne wsparte działaniami animacyjnymi i programem edukacyjnym, realizowane w szerokim kontekście ujęć odwołujących się do humanistycznej

43 Za: B. Szacka, O pamięci społecznej, „Znak” 1995, nr 5, s. 68.

44 W. Theiss, Oral history in Poland, „Words and Silence Bulletin of the International Oral History Association" 1998, nr 3, s. 38-40. 
koncepcji człowieka, jako aktywnego współtwórcy własnego środowiska, mogą stanowić, jak wskazują amerykańskie i zachodnioeuropejskie doświadczenia, punkt wyjścia do zmiany społecznej ${ }^{45}$.

Despite the fact that there are more and more contemporary academic publications on the subject of oral history understood as an element of research technique, as a separate research technique or as a specific theoretical and methodological approach, rarely do we see thorough analyses of educational potential of oral history projects realized by various institutions all over Poland. In the available publications and websites one can find information and instruction material that can serve as a starting point for the delivery of documentation projects, however, there are still few educational proposals that go beyond recording, editing and archiving of accounts. Although possibilities of using oral history in broadly understood educational field are noticed, few researches try to include this subject into broader context of contemporary pedagogical theories, concepts developed on the basis of cultural animation or discussions concerning activities for commemorating the past.

In the presented article matters relating to education and pedagogical potential of social projects using oral history technique, are analyzed in three overlapping areas, including: shaping of competences at an individual level (by people taking part in an oral history project), creation - at an institutional level - of the educational offer targeted at local communities as well as artistic projects realized by individuals and institutions with the use of oral history narrations. In the next part of the article those questions are analyzed in the context of experience with self-government cultural institution - 'Grodzka Gate - NN Theatre' Centre in Lublin realizing a documentation and animation project 'Oral History of the City', which was delivered with the perspective of broadly understood community education and it was targeted at supporting processes of reading and (re-)interpreting multicultural past of the city.
Marta

Kubiszyn

Educational implications of a documentation and animation project in the local community - between theory and practice. 'Oral history of the City of Lublin' by the 'Grodzka Gate NN Theatre' Centre 